\title{
Rotten Fruit and Cow Rumen as Local Microorganisms for Producing High-Quality Compost
}

\author{
Indasah Indasah $^{1}$, Nurina Fitriani ${ }^{2 *}$ \\ ${ }^{1}$ Institute of Health Sciences STRADA Indonesia \\ J1. Manila No. 37, Kediri, 64133, INDONESIA \\ ${ }^{2}$ Department of Biology, Faculty of Sciences and Technology, \\ Universitas Airlangga, Surabaya, 60115, INDONESIA
}

Corresponding Author

DOI: https://doi.org/10.30880/ijie.2021.13.03.002

Received 22 September 2020; Accepted 09 March 2021; Available online 01 June 2021

\begin{abstract}
Compost is an organic fertilizer that is utilized for farming to reduce the use of inorganic fertilizer. Compost utilization can improve the characteristics of soil and soil microbiology. Experiments were conducted in the Environmental Health Laboratory at Surya Mitra Husada Academy of Health, Kediri, Regional Health Laboratory of Kediri City, and Biology Laboratory and Soil Laboratory at Brawijaya University in May 2017. This study aims to discover the effects of concentration and fermentation period of rotten fruit and cow rumen on the quality of local microorganisms and compost. This study used a factorial Randomized Block Design (RBD) and 2 levels of rotten fruit and cow rumen concentration, 150 grams and 250 grams. These were fermented for different periods, 10 days and 20 days. The observed parameters were biological characteristics (bacterial population) and chemical characteristics ( $\mathrm{pH}$, Carbon $(\mathrm{C})$, Nitrogen $(\mathrm{N})$, Phosphorous $(\mathrm{P})$, and Potassium $(\mathrm{K})$.and carbon/nitrogen $(\mathrm{C} / \mathrm{N})$ ). The results show that the concentration levels and fermentation periods had significant and insignificant values. The largest bacterial populations of cellulolytic microbes were $6.65 \times 10^{6}$ (local microorganisms) and $5 \mathrm{x}$ $10^{6}$ (compost). The highest $\mathrm{pH}$ levels were 3.11 (local microorganisms) and 7 (compost). The highest temperature was $29.5^{\circ} \mathrm{C}$ (local microorganisms and compost). The highest levels of Carbon (C), Nitrogen (N), Phosphorous (P), and Potassium $(\mathrm{K})$ were $7.26,0.146,0.067$, and 0.409 respectively in Local microorganisms, while in compost, the values were $8.47,0.81,0.36$, and 0.81 respectively. The highest carbon/nitrogen $(\mathrm{C} / \mathrm{N})$ ratios were 86 local microorganisms and 11 (compost).
\end{abstract}

Keywords: Compost, concentration, local microorganisms (MOL)

\section{Introduction}

Compost is the result of partial/incomplete decomposition of a mixture of organic ingredients that can be artificially accelerated with the populations of various microbes in a warm, moist, and aerobic or anaerobic environment [1]. According to Purwasasmita [2], composting is conducted using organic waste aerobically and anaerobically [3].

Compost is a term for manmade organic fertilizer that is made from the decomposition process of the remnants of living things (plants or animals). Compost production imitates the process of natural humus formation. Through environmental engineering, compost production can be accelerated to $30-90$ days. This duration is faster than the speed of natural humus formation [4].

The natural composting process takes a quite long time. It requires $2-3$ months. Some natural composts require 6 - 12 months depending on the raw material [5]. The composting process imitates the process of natural humus 
formation that is affected by the surrounding environmental condition. Naturally, the decomposition process occurs in aerobic and anaerobic conditions alternately. Compost production can be accelerated to 30 - 90 days with the addition of EM-4, Stardec, Starbio, Orgadec, Harmony, and Fix-up Plus [6].

The elements of compost consist of two nutrient groups, namely macronutrient, and micronutrient. Macronutrients are divided into two categories, primary macronutrient, and secondary macronutrient. The primary macronutrient is the nutrient that is needed by plants in a large amount, which consists of Nitrogen $(\mathrm{N})$, Phosphorous $(\mathrm{P})$, and Potassium $(\mathrm{K})$. Meanwhile, secondary macronutrient is the nutrient required in a moderate amount, comprising $\mathrm{Calcium}(\mathrm{Ca})$, Magnesium (Mg), and sulfur (S).

Micronutrient is the nutrient that is needed in a tiny amount. It comprises Iron (Fe), Manganese (Mn), Copper $(\mathrm{Cu})$, and Zinc (Zn). Based on the Indonesian National Standard (SNI) that was issued by the National Standardization Agency of Indonesia, the quality of compost fertilizer is based on the contents of Nitrogen (N), Phosphorous (P), and Potassium $(\mathrm{K})$ is described in Table 1.

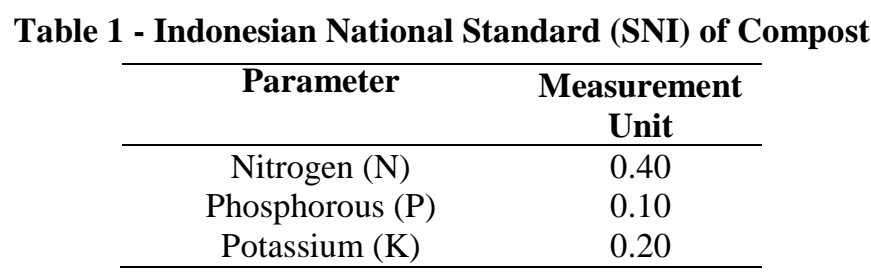

Compost is an organic fertilizer that is used for farming to reduce the use of inorganic fertilizer. The use of compost can improve the physical characteristics of soil and soil microbiology [7]. Compost contains nutrient contents such as nitrogen and phosphate in the form of complex compounds like argon, protein, and humic compounds that are hard to be absorbed by plants [8]. Many efforts have been conducted to increase nutrients in compost, such as adding natural ingredients like bone meal, banana bark, and biofertilizer [9].

Composting is the microbial process to decompose organic materials biologically using organic materials as the source of energy [10]. The natural composting process occurs for a long time and slowly. To accelerate the composting process, composting technologies have been developed. One of which is using an activator, so composting occurs more quickly and efficiently [11].

This starter that can also be self-made is known as a local microorganism that comes from easily obtained objects, such as rotten fruit, tapai, spoiled rice, fruit peel, shrimp paste, etc. Bio activator is a material that can be utilized in organic fertilizer production, natural hormone production, biogas production, etc.

Bio activator is not a fertilizer, but a material that contains effective microorganisms that actively help to decompose and ferment organic waste. Microorganisms contained in a bio activator are genetically natural and not engineered. Effective microorganisms that are contained in a bio activator comprise lactic acid bacteria (Lactobacillus $s p$.), decomposer, yeast, fungal spore, photosynthetic bacteria, and other beneficial bacteria ( $\mathrm{N}$-fixing bacteria, phosphate solvent bacteria, etc.). A study conducted by [12] found that material from slaughterhouse waste can be used as a bio activator, namely cow rumen.

Rumen consists of animal feed eaten by the livestock, which can be grass/other green feed and booster feed (concentrate). Microorganisms such as bacteria, protozoa, yeast, and fungi perform the fermentation process that occurs inside the rumen. Based on the results of isolation and microbial identification, there are xylanolytic bacteria contained in the rumen solvent, namely Bacillus sp., Cellumonas sp., Lactobacillus sp., Pseudomonas sp., and Acinetobacter sp. [13]. Moreover, Rahayu [14] stated that during isolation, anaerobic bacteria have the largest population, while there is only a tiny amount of aerobic bacteria.

Local microorganism (MOL) is a microorganism that is utilized as a starter in the production of solid organic fertilizer and liquid fertilizer. The main ingredients of local microorganisms (MOL) consist of some components, namely carbohydrate, glucose, and microorganism source. The basic ingredient for MOL solvent fermentation can be taken from an agricultural product, plantation product, and organic domestic waste. Carbohydrates as a source of nutrients for microorganisms can be obtained from organic waste, such as rice water, cassava, wheat, elephant grass, and Gamal leaf. Glucose comes from brown sugar liquid and granulated sugar as sources of energy. Coconut water and cow urine are the sources of microorganisms [15].

A MOL solvent that has been fermented can be used as a decomposer and liquid fertilizer to increase soil fertility and sources of nutrients for plants. Microorganisms are tiny living beings, which are categorized into protist that comprises bacteria, fungi, protozoa, and algae. Until now, the information about MOL utilization has not been widely known in Sulawesi [16].

According to Syaiffudin [17], MOL made of fruits contains bacteria that trigger plant growth and other bacteria that will help to increase free-living nitrogen fixation. Nitrogen is essential for plants since it functions to increase plant growth, the level of protein in the soil, and foliage plants such as vegetables and grass that propagate microorganisms in the soil [2]. 
The use of cow dung as an additional ingredient for compost production is excellent because besides fulfilling the need for nutrients, compost from cow dung can improve the physical characteristics of soil that simplifies plant development, so the results can be better. Compost from cow dung is a step of success for dryland farmers [18].

\section{Materials and Methods}

\subsection{Place and Time}

This study was conducted from May 2017 to August 2017. It took place in the Environmental Health Laboratory at Surya Mitra Husada Academy of Health, Kediri, Regional Health Laboratory of Kediri City, and Biology Laboratory and Soil Laboratory at Brawijaya University.

\subsection{Equipment and Materials}

The utilized equipment were plastic bottles, a scale, a funnel, a mixer, Kjedhal destruction set, a thermometer, UVVis spectrophotometer, a burette, a distillation flask, a hot plate, glasses, a bucket, a knife, an Erlenmeyer flask, a measurement glass, test tubes, a pipette, $\mathrm{pH}$ meter, a mixing machine, a beaker glass, petri dishes, an oven, an autoclave, a destruction tool, and a laminar airflow cabinet.

The ingredients for local microorganisms (MOL) production are cow rumen, rotten fruit waste, cow urine, rice water, coconut water, granulated sugar, brown sugar, and bra. The media used Nutrient Agar (NA); physiological saline solution $(0.85 \%)$; aluminum foil paper; plastic bag; distilled water; and chemical substances for the analysis of Nitrogen $(\mathrm{N})$ content with Kjedhal method, the analysis of available Phosphorous $(\mathrm{P})$ content with Bray 1 method, and the analysis of organic Carbon (C) with Walkey and Black method.

Dilution technique (dilution) / method of counting the number of microbial cells:

$1 \mathrm{ml}$ of sample was taken and put in $9 \mathrm{ml}$ of physiological salt or peptone buffer solution to obtain dilution of 1/10-part. $5 \mathrm{ml}$ of the sample is added to $45 \mathrm{ml}$ of diluent solution. From the 1/10 dilution solution, $1 \mathrm{ml}$ was taken and put in $9 \mathrm{ml}$ of graphical or peptone buffer solution to obtain 1/100-part diffusion.

From the 1/100 solution, $1 \mathrm{ml}$ is taken and we put it in $9 \mathrm{ml}$ of garfish or peptone buffer solution to obtain 1/1000part diffusion. Determination of $1 / 10,1 / 100,1 / 1000$ to show the ratio. This ratio is required for the conversion calculation of the number of cells present in the sample. The number of cells in each dilution suspense is represented by the number of colonies that grow on the agar plate.

\subsection{Number of Colonies $\times$ 1/Dilution}

Pour plate technique is a technique to obtaining pure colonies from a mixed population of microorganisms. This technique is done by mixing agar media which is still liquid with bacterial culture stock. The agar medium is liquefied by heating in a water bath and cooling $\left(50^{\circ} \mathrm{C}\right)$. then poured into a plate/ plate. This technique is commonly used in the TPC (Total Plae Count) test. The advantage of this technique is that the microbes that grow can be spread evenly on the agar medium.

Take a sample of $0.1 \mathrm{ml}$ from each dilution. Put it in a sterile petri dish. Immediately close the cup to avoid contaminants. The growth medium is heated first. After boiling evenly until a temperature of $40-50^{\circ} \mathrm{C}$. To isolate the bacteria, the dishes were added with Nutrient agar, while to isolate the mushrooms, $100 \mathrm{ml}$ of Dextrose Agar (PDA) potato media was added so that they could be used for 8 culture plates slowly move the petri dishes to form a figure 8 on the horizontal table to stir. A mixture of agar media with the dilution of microbial culture. After compacting, place the saucer upside down. Incubation is carried out at room temperature for 24 hours for bacteria while for fungi, incubation is carried out at least for $3 \times 24$ hours. Observe the colony characteristics of microorganisms. The parameters observed in this study were the number of isolates found, the size of the bacterial colony, the shape of the bacterial colony, the shape of the edge of the colony, and the color of the bacterial colony. Observing bacteria and observing the shape of bacterial cells. The colony morphological data obtained were analyzed descriptively.

\subsection{Research Design} follows:

The design of this study is true experimental designs. It used a factorial randomized block design (RBD) as

- First factor is the concentration of cow rumen and rotten fruit waste.

- $\mathrm{BB}_{1}$ (150 grams of cow rumen and rotten fruit +2 liters of cow urine +1.5 liters of rice water +100 grams of brown sugar +1 liter of coconut water).

- $\mathrm{BB}_{2}$ (250 grams of cow rumen and rotten fruit +2 liters of cow urine +1.5 liters of rice water +100 grams of brown sugar +1 liter of coconut water).

- The second factor is the fermentation period that consists of; (i) F1 (10-day fermentation), and (ii) F2 (20-day fermentation).

\subsection{Implementation of The Study}




\subsubsection{Local microorganisms (MOL) Solvent Production}

Local microorganisms (MOL) solvent was made by mixing all of the ingredients. The cow rumen was squeezed to extract the water, then the rotten fruit waste was ground until smooth (using a grinding machine). After that, the brown sugar or granulated sugar, cow urine, and coconut water were added according to the treatment quantity. All of the smooth ingredients and other ingredients were poured into the bucket. Afterward, the ingredients were mixed well, the bucket was closed, and it was given a plastic hose that was connected to a 1,500 ml plastic bottle that have been filled with $500 \mathrm{ml}$ of water. The MOL solvent that has been mixed was fermented according to the treatment, for 10 days and 20 days.

\subsubsection{Parameters of Observation}

The observed parameters include; (i) biological characteristic of MOL solvent such as total bacterial population, and (ii) chemical characteristics of MOL solvent, which covers pH, Carbon (C), Nitrogen (N), Phosphorous (P), and Potassium (K) and carbon/nitrogen $(\mathrm{C} / \mathrm{N})$.

\subsubsection{Data Analysis}

The data obtained from the observation were analyzed using analysis of variance with a factorial randomized block design. If the treatment showed a significant effect, the analysis would be continued with a 5\% The Boston Naming Test (BNT).

\section{Results and Discussion}

\subsection{Bio Activator of Rotten Fruit/Cow Rumen and Observation of Bacterial Colony}

Morphology obtained from this study was obtained from the bio activator of rotten fruit/beef rumen obtained from Bacillus sp. as much as $3.05 \times 102$, Azospirillum sp. as much as $1.3 \times 106$, solvent P. as much as $2.3 \times 105$, cellulolytic microbes. as much as $6.65 \times 105$ isolation of bacteria is taking or removing microbes from the environment in nature and growing them as pure culture in an artificial medium.

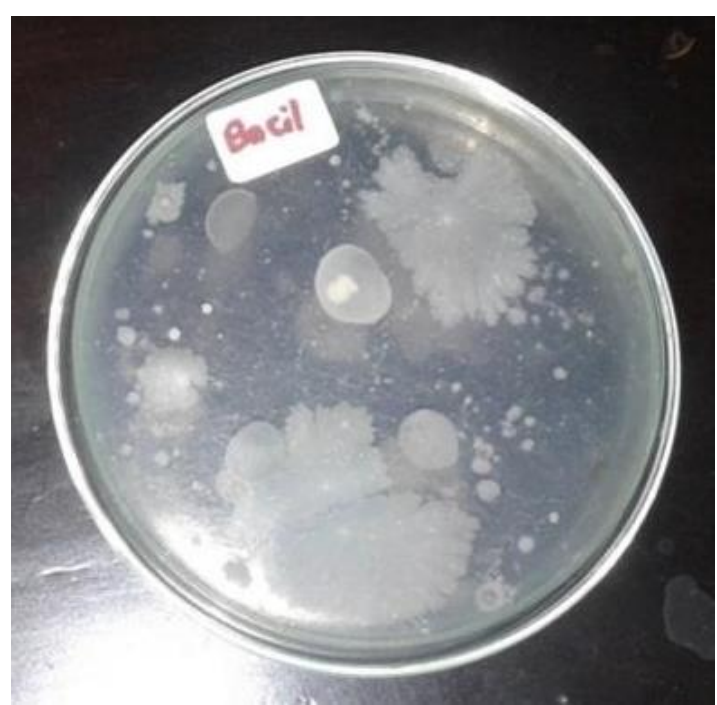

Fig. 1 - Morphology of bacillus in rotten fruit/cow rumen

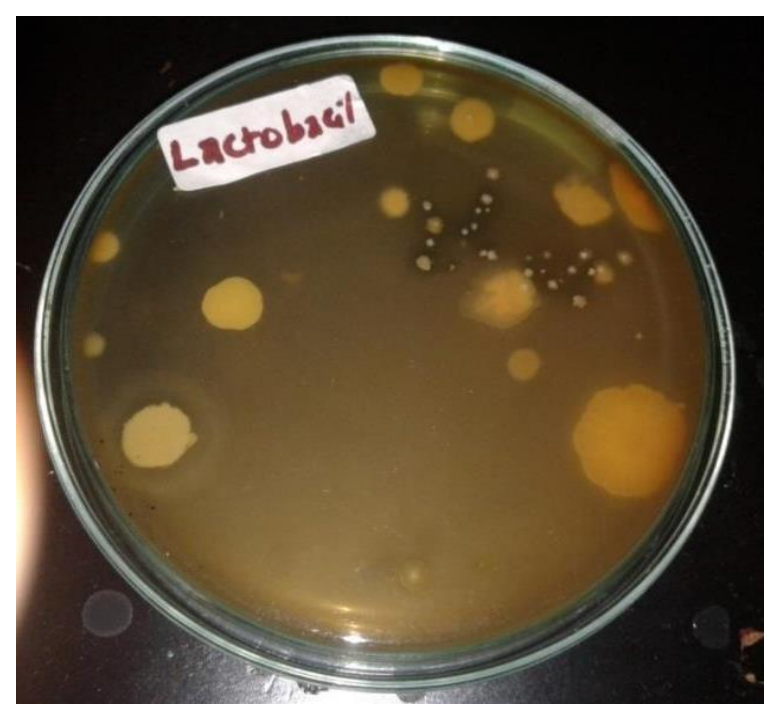

Fig. 2 - Morphology of lactobacillus in rotten fruit/cow rumen 


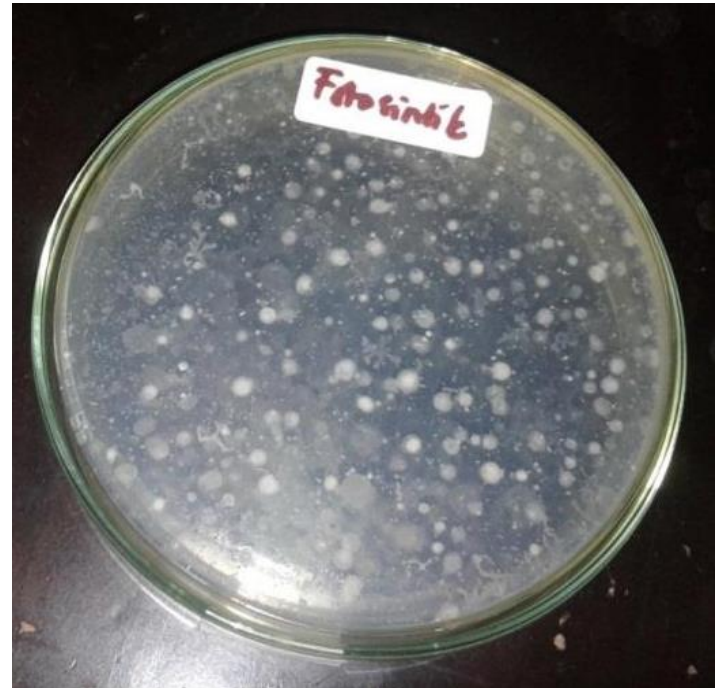

Fig. 3 - Photosynthetic bacterial morphology in rotten fruit/cow rumen

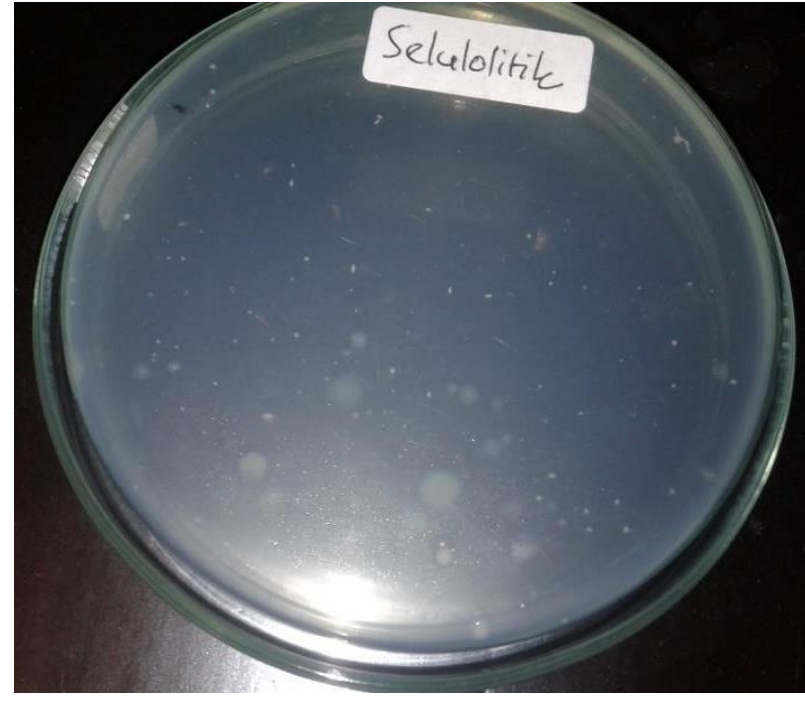

Fig. 4 - Morphology of cellulotic bacteria in rotten fruit/cow rumen

\subsection{Total Bacterial Population}

According to Trivana et al. [19], bacterial isolation is an extraction or transfer of microbes from their natural environment to an artificial medium to be cultivated as a pure culture. The more microorganisms there are in a material, the faster the organic decomposition process is. Local microorganisms (MOL) functions as a primary material to accelerate the composting process of organic matter. Fig. 5 \& Fig. 6 show bacterial contamination where more than one type of bacteria was identified inside the plate.

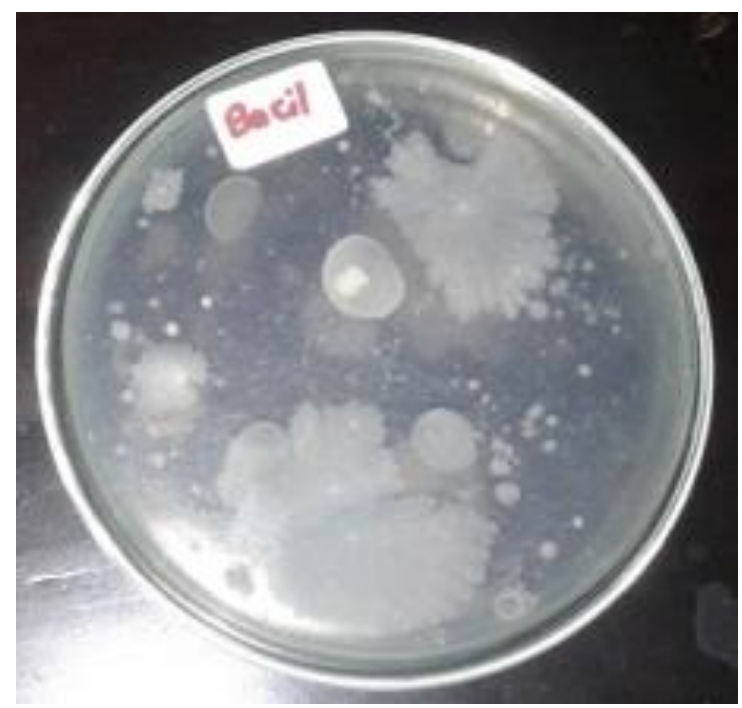

Fig. 5 - Bacillus sp.

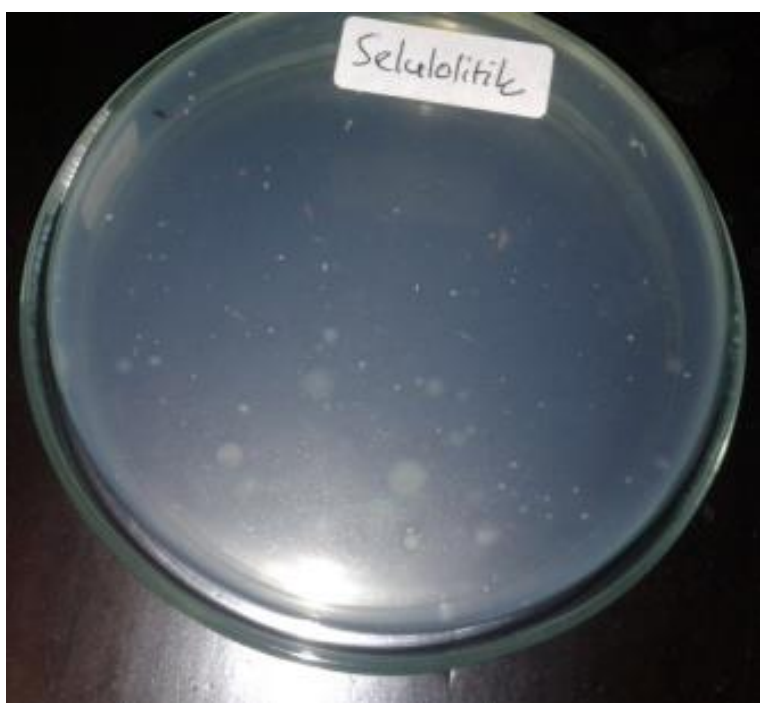

Fig. 6 - Cellulolytic microbes

Based on the results of the study, the largest bacterial population of Bacillus sp. was found in the sample with a concentration of 150 grams that was fermented for 10 days (refer Table 2). There was a decline in the sample fermented for 20 days. Meanwhile, the largest population of cellulolytic microbes was found in the sample with a concentration of 250 grams that was fermented for 20 days (refer Table 3), which experienced a decline.

Table 2 - Total Bacillus sp. in MOL solvent

\begin{tabular}{lcc}
\hline \multirow{2}{*}{ Sample type } & \multicolumn{2}{c}{ Time (day) } \\
\cline { 2 - 3 } & $\mathbf{1 0}$ & $\mathbf{2 0}$ \\
\hline BB 1 $(150 \mathrm{~g})$ & $3.05 \times 10^{6}$ & $2.15 \times 10^{6}$ \\
BB 2 $(250 \mathrm{~g})$ & $2.4 \times 10^{6}$ & $1.3 \times 10^{6}$ \\
\hline
\end{tabular}


Table 3 - Total cellulolytic microbes in MOL solvent

\begin{tabular}{lcc}
\hline \multirow{2}{*}{ Sample type } & \multicolumn{2}{c}{ Time (day) } \\
\cline { 2 - 3 } & $\mathbf{1 0}$ & $\mathbf{2 0}$ \\
\hline BB 1 $(150 \mathrm{~g})$ & $1.3 \times 10^{6}$ & $3.15 \times 10^{6}$ \\
BB 2 $(250 \mathrm{~g})$ & $2.3 \times 10^{6}$ & $6.65 \times 10^{6}$ \\
\hline
\end{tabular}

For compost, the highest total of bacteria was found in the compost with a concentration of 250 grams that was fermented for 10 days (refer Table 4). The sample fermented for 20 days had a drastic decline.

Table 4 - Total bacteria in compost

\begin{tabular}{lcc}
\hline \multirow{2}{*}{ Sample type } & \multicolumn{2}{c}{ Time (day) } \\
\cline { 2 - 3 } & $\mathbf{1 0}$ & $\mathbf{2 0}$ \\
\hline BB 1 (150 g) & $3 \times 10^{6}$ & $2 \times 10^{6}$ \\
BB 2 (250 g) & $5 \times 10^{6}$ & $1 \times 10^{6}$ \\
\hline
\end{tabular}

Fermentation occurs due to the activities of microorganisms. These activities cause a fermentation on the right organic substrate. This process can result in the characteristic change of that material. The period of fermentation is affected by factors that directly and indirectly impact a fermentation process. The fermentation period of MOL is different for each MOL ingredient type. This fermentation period is related to food availability that is used as the source of energy and metabolism for microorganisms [20].

The number of microorganisms in MOL tends to decrease after the $20^{\text {th }}$ day. This is related to food availability in local microorganisms. A long process of fermentation causes a lack of food reserve because it is used by the contained microbes [21].

\section{$3.3 \mathrm{pH}$ of Solvent}

The result in Table 5 shows the $\mathrm{pH}$ of the acid in the rotten fruit solution with a concentration of 150 grams at 20 days. This result was not much different from the concentration of 250 grams in 20 days.

Table 5 - pH of MOL solvent

\begin{tabular}{lccc}
\hline \multirow{2}{*}{ Sample type } & \multicolumn{3}{c}{ Time (day) } \\
\cline { 2 - 4 } & $\mathbf{0}$ & $\mathbf{1 0}$ & $\mathbf{2 0}$ \\
\hline BB 1 (150 gr) & 4.41 & 3.23 & 3.11 \\
BB 2 (250 gr) & 4.15 & 3.35 & 3.16 \\
\hline
\end{tabular}

The result of the study shows that the concentration and fermentation period had no significant effect on the $\mathrm{pH}$ of the compost. The highest $\mathrm{pH}$ was obtained in the treatment of rotten fruit that was fermented for 20 days with $250 \mathrm{~g}$ concentration. Afterward, although the $\mathrm{pH}$ showed the tendency to increase, there is no significant difference. The $\mathrm{pH}$ decrease at the beginning of fermentation was due to the microorganism activities that decompose organic matters in MOL, which generated $\mathrm{H}+$ ions. The effect of the 20-day fermentation period on $\mathrm{pH}$ based on $0.05 \mathrm{BNT}$ test had a significant difference with other rates. In the 20-day fermentation sample, the main ingredients of MOL have been destroyed or decomposed perfectly. $\mathrm{pH}$ acidity degree is a critical factor for the growth of microorganisms that are involved in the composting process [7].

The degree of acidity that is too high will cause an increase in oxygen consumption, which will harm the environment. Furthermore, it can also change the nitrogen substance in the compost into ammonia (NH3). Conversely, a low degree of acidity will cause a part of the microorganisms to die [5].

Table 6 - pH of compost

\begin{tabular}{cccc}
\hline \multirow{2}{*}{ Sample type } & \multicolumn{3}{c}{ Time (day) } \\
\cline { 2 - 4 } & $\mathbf{0}$ & $\mathbf{1 0}$ & $\mathbf{2 0}$ \\
\hline BB 1 (150 gr) & 7.8 & 7,6 & 7,2 \\
BB 2 (250 gr) & 7,5 & 7,4 & 7 \\
\hline
\end{tabular}

\subsection{Temperature}

A temperature increase is related to the activities of microorganisms in decomposing organic material, which generates energy in the form of heat, $\mathrm{CO}_{2}$, and steam. The heat produced by fermentation correlates with the curve of 
microorganism growth. After reaching the peak, the fermentation temperature will decrease, which is presumed to be caused by the decreasing microorganism activities in decomposing organic material.

The result of the study shows that the highest temperature of MOL solvent occurred when it was fermented for 20 days. This temperature was not much different from the room temperature, which was around $27-30^{\circ} \mathrm{C}$. The highest temperature of composting using rotten fruit and cow rumen was on the $10^{\text {th }}$ day. The temperature was always the same for every treatment. This means that the difference between the temperatures was insignificant.

Table 7 - Temperature of MOL solvent

\begin{tabular}{cccc}
\hline \multirow{2}{*}{ Sample type } & \multicolumn{3}{c}{ Time (day) } \\
\cline { 2 - 4 } & $\mathbf{0}$ & $\mathbf{1 0}$ & $\mathbf{2 0}$ \\
\hline BB 1 (150 g) & $27.0^{\circ} \mathrm{C}$ & $29.5^{\circ} \mathrm{C}$ & $29.0^{\circ} \mathrm{C}$ \\
BB 2 (250 g) & $28.0^{\circ} \mathrm{C}$ & $29.0^{\circ} \mathrm{C}$ & $29.0^{\circ} \mathrm{C}$ \\
\hline
\end{tabular}

Table 8 - Temperature of compost

\begin{tabular}{lccc}
\hline \multirow{2}{*}{ Sample type } & \multicolumn{3}{c}{ Time (day) } \\
\cline { 2 - 4 } & $\mathbf{0}$ & $\mathbf{1 0}$ & $\mathbf{2 0}$ \\
\hline BB 1 $(150 \mathrm{~g})$ & $26.98^{\circ} \mathrm{C}$ & $29.5^{0}$ & $29.0^{0} \mathrm{C}$ \\
BB 2 $(250 \mathrm{~g})$ & $28.0^{\circ} \mathrm{C}$ & $29.5^{0}$ & $29.0^{\circ} \mathrm{C}$ \\
\hline
\end{tabular}

\subsection{Organic Carbon Content}

Based on the results of the study, the highest content of carbon (C) was obtained by the sample with 250 grams of concentration that was fermented for 20 days. The acquired results show a significant difference, which means that the best MOL solvent was on the $20^{\text {th }}$ day.

Table 9 - Organic C content in MOL solvent

\begin{tabular}{ccc}
\hline \multirow{2}{*}{ Sample type } & \multicolumn{2}{c}{ Time (day) } \\
\cline { 2 - 3 } & $\mathbf{1 0}$ & $\mathbf{2 0}$ \\
\hline BB 1 (150 g) & 3.86 & 6.74 \\
BB 2 (250 g) & 5.50 & 7.26 \\
\hline
\end{tabular}

Compost with the highest value of $\mathrm{C}$ was gained by the sample with a concentration of 250 grams that was fermented for 20 days. The longer the composting period, the lower the level of carbon in the manure because microbes use carbon to reproduce [22]. Microbes take the energy for decomposing organic material from the calories generated by biochemical reactions. For example, carbohydrate changes into $\mathrm{CO}_{2}$ and $\mathrm{H}_{2} \mathrm{O}$ continuously. Thus, the content of carbon in the manure lessens [23].

Table 10 - Organic $C$ content in compost

\begin{tabular}{ccc}
\hline \multirow{2}{*}{ Sample type } & \multicolumn{2}{c}{ Time (day) } \\
\cline { 2 - 3 } & $\mathbf{1 0}$ & $\mathbf{2 0}$ \\
\hline BB 1 (150 g) & 5.23 & 8.11 \\
BB 2 (250 g) & 5.83 & 8.47 \\
\hline
\end{tabular}

\subsection{Total Nitrogen Content}

According to Kurniawan [24], the value of $\mathrm{N}$ increases and decreases during the process of bio activator production because nitrogen $(\mathrm{N})$ fluctuates. In general, the level of nitrogen in each bio activator increased. The results of the study show that the MOL solvent of rotten fruit and cow rumen with a concentration of 150 grams that was fermented for 10 days had the highest content of Nitrogen.

The compost that had the highest content of Nitrogen was the sample with the 250 grams concentration that was fermented for 20 days.

According to Ahmad [25], MOL of fruit that contains balanced content of $\mathrm{N}$ and $\mathrm{P}$ is great for the growth of vegetative plants because it has carbohydrates from rice water, granulated sugar, and fruits as the source of microorganisms. Nitrogen is a substance that composes chlorophyll, protein, and fat. 
Nitrogen is needed by microorganisms to maintain and form body cells. The higher the nitrogen level, the faster organic material is decomposed because microorganisms as compost decomposers require nitrogen to develop [26].

Table 11 - Total N content in MOL solvent

\begin{tabular}{ccc}
\hline \multirow{2}{*}{ Sample type } & \multicolumn{2}{c}{ Time (day) } \\
\cline { 2 - 3 } & $\mathbf{1 0}$ & $\mathbf{2 0}$ \\
\hline BB 1 $(150 \mathrm{~g})$ & 0.146 & 0.094 \\
BB 2 (250 g) & 0.128 & 0.114 \\
\hline
\end{tabular}

Table 12 - Nitrogen content in compost

\begin{tabular}{ccc}
\hline \multirow{2}{*}{ Sample type } & \multicolumn{2}{c}{ Time (day) } \\
\cline { 2 - 3 } & $\mathbf{1 0}$ & $\mathbf{2 0}$ \\
\hline BB 1 (150 g) & 0.59 & 0.65 \\
BB 2 (250 g) & 0.67 & 0.81 \\
\hline
\end{tabular}

\subsection{Content of Phosphorous}

Nutrient Phosphorous (P) plays a role in the growth and development of roots as well as fertilization. Fertilizer with a high level of $\mathrm{K}$ helps to form protein and mineral, and improve plant resistance to drought, pest attack, or disease [27]. The results of the study show that the MOL solvent with a concentration of 250 grams that was fermented for 20 days had the highest content of Phosphorous (P). On the other hand, the highest compost quality was obtained by the sample fermented for 20 days. These are two different things.

Microorganisms have an important role in the production of Phosphorous. Organic Phosphorous $(\mathrm{P})$ substance is transformed and mineralized into an organic compound. P substance is an organic material, so it is highly essential for soil fertility. Nutrition from organic materials can increase the level of soil nutrients to achieve optimal fertility intensity [28].

Table 13 - Content of Phosphorous (P) in MOL solvent

\begin{tabular}{ccc}
\hline \multirow{2}{*}{ Sample type } & \multicolumn{2}{c}{ Time (day) } \\
\cline { 2 - 3 } & $\mathbf{1 0}$ & $\mathbf{2 0}$ \\
\hline BB 1 $(150 \mathrm{~g})$ & 0.053 & 0.043 \\
BB 2 (250 g) & 0.067 & 0.048 \\
\hline
\end{tabular}

Table 14 - Content of $P$ in compost

\begin{tabular}{lcc}
\hline \multirow{2}{*}{ Sample type } & \multicolumn{2}{c}{ Time (day) } \\
\cline { 2 - 3 } & $\mathbf{1 0}$ & $\mathbf{2 0}$ \\
\hline BB 1 $(150 \mathrm{~g})$ & 0.24 & 0.36 \\
BB 2 $(250 \mathrm{~g})$ & 0.29 & 0.35 \\
\hline
\end{tabular}

\subsection{Content of Potassium}

Macronutrients required by plants are Nitrogen, Phosphorous (P), and Potassium $(\mathrm{K})$. Nitrogen $(\mathrm{N})$ is beneficial for the growth of shoots, stems, and leaves. Phosphorous $(\mathrm{P})$ is used to stimulate the growth of roots, fruits, and seeds. Potassium $(\mathrm{K})$ is needed to increase plant resistance to pest attacks and diseases [28].

The results show that the MOL solvent that was fermented for 10 days had the highest content of potassium. Meanwhile, the highest quality of compost was obtained by the treatment with the 20-day fermentation and the 150 grams concentration. Potassium is used by microorganisms in substrate material as a catalyst. The presence of bacteria and their activities will greatly affect the content of potassium. Potassium can be fixed and stored in cells by bacteria and fungi [19].

According to Purwasasmita [2], the microorganisms that fix potassium come from organic material that has been decomposed by microorganisms in compost material. Compost material that is fresh and organic contains potassium in the form of complex compounds that cannot be directly used by the plant to grow. However, with the activities of 
decomposing microorganisms, the complex compounds can be transformed into simple compounds that eventually generate potassium substances that can be absorbed by plants. Essentially, potassium has a significant role in photosynthesis to form proteins and cellulose. Besides, it can also strengthen the stem of a plant, which also makes it able to increase plant resistance.

Table 15 - Content of Potassium in MOL solvent

\begin{tabular}{lcc}
\hline \multirow{2}{*}{ Sample type } & \multicolumn{2}{c}{ Time (day) } \\
\cline { 2 - 3 } & $\mathbf{1 0}$ & $\mathbf{2 0}$ \\
\hline BB 1 (150 g) & 0.393 & 0.246 \\
BB 2 (250 g) & 0.409 & 0.254 \\
\hline
\end{tabular}

Table 16 - Content of Potassium $(\mathbf{K})$ in compost

\begin{tabular}{ccc}
\hline \multirow{2}{*}{ Sample type } & \multicolumn{2}{c}{ Time (day) } \\
\cline { 2 - 3 } & $\mathbf{1 0}$ & $\mathbf{2 0}$ \\
\hline BB 1 (150 g) & 0.62 & 0.81 \\
BB 2 (250 g) & 0.64 & 0.55 \\
\hline
\end{tabular}

\subsection{C/N Ratio}

The value of the Carbon/Nitrogen $(\mathrm{C} / \mathrm{N})$ ratio highly depends on the activities of microorganisms in the soil. In an intensive weathering process, there is a rapid change in the soil. Heterotrophic bacterial flora, fungi, and actinomycetes become active, reproduce rapidly, and produce a lot of $\mathrm{CO}_{2}$. In this condition, nitrate disappears from the soil because the nitrogen is consumed to form the bodies of microorganisms [29]. Therefore, the lower the $\mathrm{C} / \mathrm{N}$ ratio, the more intensive the weathering.

Based on the results of the study, the MOL solvent with the highest $\mathrm{C} / \mathrm{N}$ level can be obtained in 20 days, while the best compost quality can be obtained in 10 days. If the $\mathrm{C} / \mathrm{N}$ content is higher, the compost is not mature enough and requires a longer decomposition period [30]. Compost is mature if the $\mathrm{C} / \mathrm{N}$ ratio is $<20$ [31]. One of the indicators that signify the decomposition process in composting is the decomposition of the $\mathrm{C} / \mathrm{N}$ substrate by microorganisms or other decomposers. The change of the $\mathrm{C} / \mathrm{N}$ ratio occurs during decomposition since carbon is used as a source of energy and it disappears in the form of $\mathrm{CO}_{2}$, so the carbon content decreases over time [32].

The longer the decomposition process, the smaller the $\mathrm{C} / \mathrm{N}$ ratio [33]. The content of Carbon in compost material reduces a lot since it is used as a source of food/energy. On the other hand, the content of nitrogen increases because the decomposition process of compost material using microorganisms produces ammonia and nitrogen. Thus, the $\mathrm{C} / \mathrm{N}$ ratio decreases.

Table 17 - C/N ratio in MOL solvent

\begin{tabular}{ccc}
\hline \multirow{2}{*}{ Sample type } & \multicolumn{2}{c}{ Time (day) } \\
\cline { 2 - 3 } & $\mathbf{1 0}$ & $\mathbf{2 0}$ \\
\hline BB 1 (150 g) & 36 & 86 \\
BB 2 (250 g) & 45.75 & 74.25 \\
\hline
\end{tabular}

Table 18 - C/N ratio in compost

\begin{tabular}{ccc}
\hline \multirow{2}{*}{ Sample type } & \multicolumn{2}{c}{ Time (day) } \\
\cline { 2 - 3 } & $\mathbf{1 0}$ & $\mathbf{2 0}$ \\
\hline BB 1 (150 g) & 11 & 10 \\
BB 2 $(250 \mathrm{~g})$ & 10 & 9 \\
\hline
\end{tabular}

\section{Conclusion}

From this study on the quality analysis of local microorganisms (MOL) solvent and compost from rotten fruit and cow rumen, it can be concluded that the concentration of rotten fruit and cow rumen and the period of fermentation has insignificant effects on the sole factor, especially MOL solvent content. The largest bacterial population in the MOL solvent was cellulolytic microbes. The best $\mathrm{pH}$ fermented for 20 days. The highest temperature was fermented for 20 
days. The highest content of organic $\mathrm{C}$ with the 250 grams concentration that was fermented for 10 days. The highest content of $\mathrm{N}$ with the 150 grams concentration that was fermented for 10 days. Meanwhile, in compost, it was obtained by the 150 grams sample was fermented for 20 days. The highest content of fermented for 10 days. On the other hand, the highest content of $\mathrm{P}$ in compost was found in the 20-day fermentation sample. The highest $\mathrm{K}$ in the 250 grams sample was fermented for 10 days. Meanwhile, in compost, it was found in the 150 grams sample that was fermented for 20 days. The best $\mathrm{C} / \mathrm{N}$ ratio with a concentration of 150 grams was fermented for 20 days. Meanwhile, in compost, it was found in the sample with the same concentration that was fermented for 10 days.

\section{References}

[1] Crawford J. H. (2003). Kompos. Bogor

[2] Purwasasmita M. (2009). Mikroorganisme Lokal Sebagai Pemicu Siklus Kehidupan. Jakarta

[3] Purwendro N. S. (2006). Mengolah Sampah Untuk Pupuk Pestisida Organik. Penebar Swadaya. Jakarta

[4] Yuwono D. (2006). Kompos. Penebar Swadaya. Jakarta

[5] Djuarnani N., Kristian \& Budi S. (2009). Cara Cepat Membuat Kompos. Agromedia Pustaka. Jakarta

[6] Yovita H. I. (2007). Membuat Kompos Secara Kilat. Jakarta

[7] Elpawati, Dara S. D. \& Dasumiati (2015). Optimalisasi penggunaan pupuk kompos dengan penambahan Effective Microorganism 10 (EM10) pada produktivitas tanaman jagung (Zea mays L.). Jurnal Bilogi, 8, 77-87

[8] Setyotini A. E. \& Saraswati D. R. (2016). Kompos, Pupuk Organik dan Pupuk Hayati. Jakarta

[9] Simanungkalit R. D. M., Suriadikarta D. A., Saraswati R., Setyorini D. \& Hartatik W. (2006). Pupuk Organik dan Pupuk Hayati. Balai Besar Penelitian dan Pengembangan Sumberdaya Lahan Pertanian

[10] Dewi I. (2012). Pengolahan sampah skala rumah tangga menggunakan metode composting. Fakultas Teknik LIMIT'S, pp. 35-48

[11] Arisha H. M. E., Gad A. A. \& Younes, S. E. (2013). Response of seome pepper cultivar to organic and mineral nitrogen fertilizer under sandy soil conditions. Zagazig Journal of Agricultural Research, 30, 1875-1899

[12] Sinaga H. (2011). Penggunaan Rumen Sapi sebagai aktivator Pada pembuatan Kompos daun Lamtoro. Medan

[13] Lamid K. M., Chuzaemi S. \& Puspaningsih N. (2006). Inokulasi bakteri xinalolitik asal rumen sebagai upaya peningkatan nilai nutrisi jerami padi. Jurnal Hasil Resit, 14(2), 1-6

[14] Rahayu E. (2003). Lactic acid bacteria in fermented food of Indonesian origin. Jurnal Agritech 23(2), 75-84

[15] Darwis S. N. \& Indo M. (1992). Teknologi Fermentasi Budidaya Selada. Rajawali Press

[16] Suhastyo A. A. (2011). Studi Mikrobiologi dan Sifat Kimia Mikroorganisme Lokal Yang Digunakan Pada Budidaya Padi Metode SRI (System of Ric Intensification). Bogor

[17] Syaifuddin A., Mulyani L. \& Sulastri E. (2010). Pemberdayaan Mikroorganisme Lokal Sebagai Upaya Peningkatan Kemandirian Petani. Jakarta

[18] Wiskandar (2002). Peran Pupuk Kandang Untuk Memperbaiki Sifat Fisik Tanah Di Lahan Kritis. Kongres Nasional VII

[19] Trivana L., Pradhana A. Y. \& Manambangtua A. P. (2017). Time optimization of the composting of organic fertilizer based on goat manure and coconut coir dust using EM4 Bio-Activator. Jurnal Sains dan Teknologi Lingkungan, 9(1), 16-24

[20] Sriwati R., Chamzurni T. \& Sanjani A. (2013). Trichoderma virens isolated from cocoa plantation in Aceh as biodecomposer cocoa pod husk. Jurnal Natural, 13(1), 6-14

[21] D. A. N. B. U. (October 21, 2009). Mempercepat, "Disampaikan pada Acara Pertemuan Rutin Kelompok PKK Dusun Sangubanyu Sumberrahayu Moyudan Sleman”. Indonesia

[22] Murtalaningsih (2010). Studi Pengaruh Penambahan Bakteri Dan Cacing Tanah Terhadap Laju Reduksi Dan Kualitas Kompos. Laporan Tugas Akhir, Institut Teknologi Sepuluh Nopember

[23] Subali E. B. (2010). Pengaruh Waktu Pegomposan Terhadap Rasio Unsur C/N Dan Jumlah Kadar Air Dalam Kompos. Semarang

[24] Kurniawan A. (2014). Pengaruh dosis kompos berbahan dasar campuran feses dan cangkang telur ayam terhadap pertumbuhan tanaman bayam cabut (Amaranthus tricolor L) sebagai sumber belajar biologi SMA kelas XII. JUPEMASI-PB10, 1, pp. 69

[25] Ahmad. (2013). Mikroorganisme Lokal, Solusi Bagi Petani. http://isroi.wordpress.com

[26] Raras N., Hadid A. \& Burhanuddin L. (2018). Pengaruh Mikroorganisme Lokal Buah-Buahan (Lactuca sativa L.). Jurnal Faperta Untad, 6(1), 127-135

[27] Purwa D. R. (2009). Petunjuk Pemupukan. Jurnal Agriceca, 3(4), 7-11

[28] Santi S. S. (2009). Kajian Pemanfaatan Limbah Nilam Untuk Pupuk Cair Organik Dengan Proses Fermentasi. Teknik Kimia, pp. 170-175

[29] Soepardi G. (2013). Sifat Dan Ciri Tanah 1. Institut Pertanian Bogor

[30] Tambunan E.R. (2009). Respon Pertumbuhan Bibit Kakao Pada Media Tumbuh Sub Soil Dengan Aplikasi Kompos Limbah Pertanian Dan Pupuk Anorganik. Universitas Sumatera Utara

[31] Mathur S. P., Owen G., Dinel H. \& Schnitzer M. (2013). Determination of compost biomaturity. Biological 
Agriculture and Horticulture, 10(2), 65-85

[32] Graves R. E., Hattemer G. M., Stettler D., Krider J. N. \& Dana C. (2010). National Engineering Handbook. Departmen of Agriculture

[33] Surtinah (2013). Pengujian kandungan unsur hara dalam Kompos yag berasal dari serasah tanaman jagung manis. Jurnal Pertanian, 11(1), 16-25 